\title{
Airway Resistance
}

National Cancer Institute

\section{Source}

National Cancer Institute. Airway Resistance. NCI Thesaurus. Code C120927.

An assessment of the opposition to airflow through the respiratory tract on inspiration and/or expiration. 